\title{
Study on the Reasons of Chinese Painting Art from Realistic Writing to Freehand Brushwork
}

\author{
Chao Chen \\ Minjiang University \\ Fuzhou, China 350000
}

\begin{abstract}
Chinese painting is a traditional one with a long history and fine tradition. It embodies the wisdom, character, psychology and temperament of the Chinese nation, and has a unique system in the world painting garden with its distinctive features and style. The Chinese painting has different genres, characters, theories and works in thousands of years development, but in general, Chinese painting is divided into two important directions: realistic writing and freehand writing. From the perspective of history, the early Chinese painting was dominated by realistic writing, and flourished in the Sui, Tang and early northern Song dynasties. From the later period of the northern song dynasty to the end of the southern song dynasty, Chinese paintings began to appear in the first place, mainly in the form of freehand brushwork. The Chinese paintings in the Yuan dynasty were mainly composed of freehand brushwork, and so do as the Ming and Qing dynasties. Thus the Chinese paintings are now also called "freehand paintings". Therefore, it is of great practical significance to study Chinese painting art from realistic writing to freehand writing. It can further clarify the general direction of the development of Chinese painting, enrich and supply the theoretical connotation of the specific reason of Chinese painting art from the realistic writing to writing, thus providing further, multi-angle theoretical support and supplement for carrying forward the traditional culture and art of the nation.
\end{abstract}

Keywords-Chinese painting; realistic writing; freehand brushwork

\section{INTRODUCTION}

The research on the reasons of Chinese painting from realistic writing to freehand writing is currently in relatively scattered studies both at home and abroad, and there is no comprehensive study on various specific reasons, no sufficient and comprehensive theoretical arguments, and no systematic and in-depth research results. This is a study of Chinese painting art from realistic writing to the purpose of writing, Mainly from historical reasons (the change of artists' mood caused by the change of dynasties and social changes, the artistic creation oriented towards freehand writing) and the reasons for the development of artistic theories (the emergence of the artistic theory of Chinese painting and the need to promote the meaning of art in Chinese painting) and the reasons for the development of artistic techniques (regional change, theoretical development, etc., the corresponding creative expression techniques have been developed to further accord with Chinese painting to focus on freehand writing) and the reasons for the development of materials technology (the production and extensive use of Xuan paper). The expressive techniques can vividly show the effects of rich changes, which are in line with the artistic requirements of the theory and reality of freehand writing.

\section{HistoricAl PROGRESS AND SOCIAL CHANGE LEADING} TO THE CHANGE OF CHINESE PAINTING TOWARDS THE GOAL OF FREEHAND BRUSHWORK

In 1279 , with the death of the southern Song dynasty, the Yuan dynasty entered into the central plains of Han dynasty and began the reign of foreign people. From the perspective of the central plain Han dynasty, this was the first comprehensive and direct foreign rule, which was not good or bad for historical progress and social change. However, the changes and impacts brought by it were diverse and varied, including the impact on the art field, which was the first one of the influence of objects and people, and the object was the academy organization, and the people were artists. First of all, after the accumulation of the previous dynasties, the academy had reached a high point in the two Song dynasties, especially during the reign of emperor Hui Zong of the late Song dynasty. The royal family directly participated in the construction and operation of the institution of the academy of painting, which was quite complete in terms of institution setting, personnel scale and system construction. Painters in art academies, made painting except for court decorative painting, but also painted the ancient emperors, sages, or the actual life portrait of ministers, bureaucrats, etc according to the will of the emperor and the feudal moral standards, and the classification "faithful or wicked, good or evil". The academy also collects folk paintings and enriches palace collections for academic research. However, the works of the painters of the two Song painters were mainly influenced by the royal consciousness and practical function, and their creation and theory followed the style and aesthetics of the previous dynasties. In addition, the influence of the academic thought influenced the development of the paintings, which were similar, realistic and physical, and the study of physical, physical property and physical states was in place. This kind of painting is known as "courtyard painting" in the history of Chinese painting, which is characterized by accurate modeling, rigorous method, colorful colors and realistic appearance. In the early period of the northern Song dynasty, Han Qi said "The art of painting is only realistic" in "the art of painting", which means "courtyard painting" is the painting of realistic writing. However, Yuan 
dynasty which got the government by the horses and weapons prefer military to civil, favoring military hardware not art culture. The established art institute of the two song dynasty has been badly destroyed, and it has led to the decline of realistic painting and writing. In terms of the people, the management of the Yuan dynasty in the political and cultural fields is different. Politically, it adopts the harsh policies to divide the national population into four grades, namely, the Mongolians as the ruling ethnic group as the first class. Secondly, according to the time sequence of the conquered regions, the people are divided into three levels: the eyes colored, the Han and the south. The political treatment of these four people is different, and they are treated differently in terms of office, imperial examination and criminal law. Among them, the original Song dynasty was the fourth and southerner (also known as the "Barbarian"), which refers to the original southern Song dynasty (Jiang Zhe, Jiangxi province, $\mathrm{Hu}$ Nan province and the southern province of Henan province in Yuan dynasty). In the history of the first hundred years, the Yuan has failed to take a test in seven or eight decades, blocking the road to the south's political path. Therefore, as untouchable artists, they suffer from the depression and oppression caused by the unfair treatment of foreign powers. The double change of country broken and personal circumstances makes people's inner unhappiness become the pushing hand of artistic style, and the cultural policy of the Yuan dynasty is relatively loose, making art change without political lock. The original "courtyard drawing" artists are no longer required to draw on the royal will, and the work of creation has to be transformed from duty to pleasure. The artists of this period have more time and freedom to live in mountains and forests, and indulge in calligraphy and painting, so as to entertain themselves, relieve their worries, and express their own soul. The historical progress and social change of the Yuan dynasty made the painting style of realistic writing represented by the "courtyard painting" began to decline, and the painting style of "literati painting" was officially introduced.

\section{The DEVElopment OF "Literati PAINTING" IN THE ART THEORY PROMOTED CHINESE PAINTING TO FOCUS ON WRITING}

The development of Chinese painting to the two Song dynasty forms the painting skills and theories that are similar to the Buddhist law. It is a skill to reproduce the objective things depicted in detail. In fact, this is a kind of imitation, similar to the theory of western art, which originated from imitation theory. And the ultimate purpose of art is to imitate? Is this the essence of art? Blindly in the imitation of the realistic writing content representation cannot meet the needs of times and art development, some wide culture artists discovered the problem, and a different approach from theory and practice, the theory of "literati painting" gradually are put forward. If we take a serious look at the works of various dynasties in China, we will find that there has been a significant change in Chinese painting before and after the end of the northern Song dynasty and the beginning of the Yuan dynasty. In the late northern Song dynasty, the Chinese paintings did not form the three forms of "poetry and calligraphy and painting", and the Chinese painting after the early Yuan dynasty basically formed the form of "poetry and calligraphy and painting" in one form and spread to the later generations. "Poetry and calligraphy" is one of the unique aesthetic forms and characteristics of Chinese painting. And the Chinese painting of "poetry and painting" is one of the "literati paintings" advocated by freehand brushwork. The notion of "literati painting" in Wei, Jin and Tang dynasties have sporadic in a little scale, by Su Shi advocated actively in Northern Song dynasty, and by Zhao Mengfu put forward formally. The theory of "literati painting" is the most important and representative theory in the development of Chinese painting art, which has a great influence on later generations. It can be said that Chinese painting follows this route after the proposal of "literati painting" theory. The "poem calligraphy" in the "literati painting" three as one respectively is poetry and referring to literature, poetry books that calligraphy and refers to techniques to painting, painting is painting a picture, the general can be summarized as the relationship of poetry and painting, the relationship between books and paintings. First of all, the relationship between poetry and painting, First of all, the relationship between poetry and painting, Su Shi at the end of the northern song dynasty came up with a poem of "flavor and poetry", which included painting in the poem. There is a common view of poetry in painting and poetry in the painting. The paintings and poems have similarities, and they complement each other. Poetry is an extension and expression of the unutterable meaning of the painting, and the painting is the concrete manifestation and embodiment of the poem. Painting has the poetic meaning, this kind of painting is the painting of the mind. Once again, the relationship between books and paintings has been discussed in the previous theories of "literati painting". For example, the famous paintings of the past dynasties by Tang Zhangyan have "the Angle of the mountain, the main chapter... It is known that the calligraphy and painting are different and the same body, which is only the combination of the origin of words and painting. Compared directly to the calligraphy and painting in the technique level, to discuss is the early Yuan dynasty Zhao Mengfu in the postscript show stone Shu Lin figure of "stone such as Zhou malapropism wood, bamboo also write eight method shall be, if someone can also this, know the calligraphy and painting with" originally, this is the theory of painting and calligraphy ink common sentence after the impact. In Yuan dynasty, the brushstroke of calligraphy in the painting has been pushed to the full maturity stage. In the painting almost every line, every point is covered with the pen of calligraphy, the painting and calligraphy of the same origin, with the book in the painting. Therefore, the three literati paintings of "poetry and painting" embody the multi-aspect cultivation and higher aesthetic requirements of the painter in literature, calligraphy and painting, and the simple reproduction of the imitative style of realistic writing and painting, which greatly enriches the connotation and interest of Chinese painting, and conforms to the needs of the development of The Times and the art itself. Painting is the art of reflecting the form, and form occupies an important position as the body of painting. In the view and understanding of the form in painting, the understanding of shape is also gradually developed in the theory and practice of Chinese painting. The early painting focuses on the realistic writing, like the six 
dynasties of the Liuxiang, the "the paintings of the landscape", "Wherever you are, and whatever you can see, the painting is shape and color as origins." In fact, the requirements of landscape painting should be based on natural objects, not only to observe the shape and color of objects, but also to show them faithfully through painting. And as Tianren Shaikh's theory of "six method of article 4 of article 3", the "object" and "Suilei Fucai ", respectively is refers to the painter portrayed to the reflected object shape, made color will be similar to draw the object. And as in the early days of the northern Song dynasty, Guo Ruoxu said in "the painting of a picture" and the "Those who draw feathers must know the names of the birds. Since the beaks, face, mouth, eye rim, jungle, brain, wearing domain, wing tip wing, clam wings, a small bar, big alveolus feathered wings bond, and six tip, and the wind, grazing grass, loose end, pressure tail, belly, legs hakama, tail cone, food claw feet have leaned claw (three) and (2), liao claw (four), hold claw (section)..." The artist was asked to observe the object in such an objective and detailed manner as to require the painter to draw in accordance with the standard of a biologist. However, in the late northern song dynasty, the "literati painting" began to appear, and the theory of shape was changed, and the most famous one was Su Shi's "theory of painting, which is similar to that of children", which means that it cannot be confined to shape, and can't pursue "likeness". Because of the shape of the work, even though it's a piece of work, it's not the life of art, at least the value of art is reduced. It is the mere appearance of the skin of things that does not embody the spiritual substance of things, but the purpose of painting without power. To the Yuan dynasty, Ni Zan said in "Answer Zhang Zhongzao" that "the so-called painter of the servant, but the pen is sketching, do not look like, just to entertain the ear". In the theme of "self-painting bamboo", it is also said that "the bamboo of $\mathrm{Yu}$ bamboo is to write in the chest of the ear, not to be more similar, the leaf of the numerous and sparse, the branch of the oblique and straight!" The purpose of the painting is not to depict the specific image, but to write it in the chest, to achieve the freedom of the mind. This new Angle opens the understanding of the shape of Chinese painting and the purpose of painting. The Chinese painting began to transform from writing shape to writing freehand, and from the table to the mental image. The development of the theory of art, especially the proposal of "literati painting", guided Chinese painting in the field of thought and aesthetics to focus on freehand brushwork.

\section{THE ENRICHMENT AND DEVELOPMENT OF THE TECHNIQue FIT THE AESTHETIC CONNOTATION OF CHINESE PAINTING}

Chinese painting inheritance has been divided into brushwork techniques and freehand brushwork techniques, while the technique of calligraphy is represented by the calligraphers, and the techniques of freehand painting are represented by literati painters. From the extant Chinese painting works, the early Wei and Jin dynasties, especially the two Song dynasties, were the period of elaborate-style painting. Elaborate-style painting technique is divided into general outline and applies two kinds of color, pure, delicate and accurate outline is the line draw the outline of the painted object, the line can be divided into the iron line according to the image, ancient eighteen trace hair and nail head rat tail said. The application color is the color of the painted images in the lines drawn, which can be divided into two parts: dyeing, covering, etc., and the painting effect is exquisite and realistic. It is very consistent with the aesthetic connotation of the realistic writing of Chinese painting. The characteristics of this technique are first of all, the procedure is serious. For example, we need to outline the contour first, and then dye, cover, dye, etc. In order to dye the color of the plant before coloring, sometimes we have to wait for the color before it can be colored again, etc. These programs cannot be reversed step-bystep. Secondly, it is necessary to be careful when painting, to be very patient and otherwise it will be ruined. Finally, due to the painting procedure and the reason of the representation, the completion of the painting is relatively long. This style of painting is constrained by physical objects, and it is difficult to show the needs of the painter's own painting, and his position is gradually replaced by the ink written by the literati. In addition, after the death of the northern song dynasty, the capital was moved to the southern song dynasty. When they came to Jiang Nan, they had a difficult problem, which was that they were good at displaying the hard and angular techniques of the northern mountains and rivers, difficult to reflect the landscape of Jiang Nan. After long-term practice and improvement on the basis of the predecessors, the original performance techniques of the northern mountains and rivers are mainly represented by the surface, and the transformation form is mainly based on the performance techniques of the line, while the performance techniques of the line mainly correspond with the line oriented calligraphy and the requirements of the book painting. In addition, there are new techniques, such as the new technique of "erasing" in landscape painting techniques. In the early period of the northern song dynasty, there was no "brush" this technique. For example, in the early period of the northern song dynasty, the "Xishan Travel Map", which depicts the outline of the mountain and the veins of the stone with the strong and strong strokes of the brushwork, was formed in a dense short point, intersected along the contour of the outline, and finally, there was no obvious mixing and blending between the box and the cold, and the techniques were relatively independent. In the late period of the northern Song dynasty, the paintings of the landscape paintings of "The Pine-Soughing Valleys" were in the southern Song dynasty and the landscape of the four mountains was basically the same. It was not until the early Yuan in landscape painting "brush" this new technique, " brush $"$ is actually will hook and Cun ambiguous fusion techniques, its role is to hook Cun organic unification, more overall one integrated mass. This can be seen in the landscape paintings of the early Yuan dynasty, such as Huang Gongwang's "Fu Chun Mountain House", Ni Zan's "Rong Qi Zhai" and so on. At the same time, the fusion of the technique program is the technique of "hook belt and cold". In the early stage, the technique of landscape painting is more independent, and the method of "linking and chapping" is presented in the technique of landscape painting after the beginning of the Yuan. On the one hand, it is more suitable to depict the landscape of Jiang Nan, and the other party is more consistent with the aesthetic connotation of writing. 


\section{The Production of Xuan Paper And Its Extensive USE CONFORM TO THE REQUIREMENTS OF CHINESE PAINTING FREEHAND WRITING}

The preamble cloud of "Xiao Ling Cao's Family Tree" rebuilt in Qian Long period: "At the end of the song dynasty, there was a lot of confusion. In the third year of Cao's junior year, he came to Xiaoling,. He was divided into thirteen houses. There are mountains with little land to grow plants. Then he leaned Cai Lun's paper creating to make a living." According to this record, we can see that in the late song dynasty, Cao moved to Jing Xian Xiao Ling in the middle of the Song dynasty, to make Xuan paper as an industry and passed on from generation to generation. Xuan paper is the most common and widely used material in Chinese painting. It is easy to preserve, not brittle, and will not fade, so it has a reputation of "paper longevity". The raw materials of Xuan paper are processed by more than 100 processes, such as green sandalwood peel and shatin straw. On May 20, 2005, the state council approved the inclusion of the first batch of national intangible cultural heritage list. However, before the Xuan paper market and the most extensive use, the Chinese painting used a kind of silk fabric called "silk". From the perspective of the existing paintings, the time period of the late Song dynasty and the early Yuan dynasty was a more obvious cut-off point for silk and Xuan paper. The paintings of the period were mainly painted by silk, and the paintings from the beginning of the Song dynasty to the later period were widely used for drawing. So why is the paper produced and widely used to promote Chinese painting from the material craftsmanship to the focus of freehand writing? It also needs to be explained by the characteristics of Xuan paper. The core of Chinese painting is - "pen and ink", and Xuan paper is unique to the bearing of pen and ink. Through the microscope, we can see that there are more fiber long shafts on the sandalwood fiber cells of the paper, and the dense distribution of the parallel wrinkles is uniform, and the natural structure is very easy to retain the ink marks. Light ink and water are gradually diffused outward, heavy ink self-dividing line is not confused with each other, combined with the combination of leather and grass length fibers, the water ink spreads evenly. The ink contact paper produces a rich blotting effect, which is weak in the thick, thick in the light, and has a clear and distinct change in the expression of the ink rhyme. And as a result of the paper fibers absorb the dense bleeding after the inky, from the center to the decrease in turn around type diffusion, compared with silk dependent on water flow and the ink is more exquisite and more subtle changes. Therefore, Xuan paper is very sensitive to the reaction of any point line formed by ink, and can reflect the urgency of the speed of the artist's pen. At the same time, the paper has a good display of the ink on the paper surface, such as shun feng, reverse front, and twisting, kneading, potting, etc., and the marks on the paper surface are very good, which further enlarges the expressive force of the painting. In addition, it also intuitively reflects the artist's creative state and state of mind, which can reflect the artist's spiritual temperament and soul portrayal. Therefore, the characteristics of Xuan paper are very consistent with the aesthetic and technical requirements of the painting, which are greatly superior to the expressiveness of silk. And it is based on rice paper two core of Chinese painting - "pen and ink" has abundant performance and bearing of skills, combined with the economically paper relatively cheaper and more accessible and silk paper gradually replaced the silk. Instead of silk, paper flourishes, while freehand writing is a substitute for realistic writing. Therefore, the Chinese painting has a special internal relationship with the creation and extensive use of writing and writing. Especially after the Ming and Qing dynasties, the paper process was more advanced, and the paper was more sensitive to ink, reflecting the more subtle and rich changes of the pen, which played a crucial role in the rapid development of the later freehand paintings.

\section{CONCLUSION}

To explore and analyze the development of art in China, it has important theories and practical ideas for further inheritance and development of Chinese painting. From the above mentioned, we can conclude that the art of Chinese painting turns from realistic writing to freehand writing, which is not the beginning of a certain day in a certain year. Instead, it is developed by the corresponding mature factors of various factors. It is a process of gradual germination and development over a long period of time. In addition, from the evidence and demonstration of the existing data, the process of development and germination is more concentrated in the period of 200 years in the late northern song and southern song and Yuan dynasty. Among them, the four most important factors that promote the art of Chinese painting from realistic writing to freehand writing are historical development factors, artistic theory development factors, artistic techniques development factors and material technological development factors, and there are many influences between them. This paper starts from the four aspects of the systematic discussion of cause of the Chinese painting art from the realistic writing to the freehand writing, just to make the jade bricks for reference.

\section{REFERENCES}

[1] Cao Tiansheng. History of Chinese Xuan Paper [M]. Beijing: China Science and Technology Press, 2005. 曹天生.中国宣纸史[M].北京: 中国科技出版社, 2005 .

[2] Ling Hubiao. Research On The Painting Institute Of Song Dynasty [M] Beijing: People's Fine Arts Press, 2011. 令狐彪.宋代画院研究[M].北 京: 人民美术出版社, 2011.

[3] Cao Qing. Painting Research In Jiang Su Province of Yuan Dynasty [M]. Jiangsu: Southeast University Press,2013. 曹清.元代江苏绘画研 究 $[\mathrm{M}]$.江苏: 东南大学出版社,2013.

[4] Fu Huimin. Interpretation Of Ancient Chinese Painting Theory [M] Shanghai: Shanghai People's Fine Arts Press,2017. 傅慧敏.中国古代 绘画理论解读 $[\mathrm{M}]$. 上海: 上海人民美术出版社,2017.

[5] Gong Yin. History of Chinese National Policy [M]. Sichuan: Sichuan People's Press,2006. 龚荫.中国民族政策史[M].四川: 四川人民出版 社,2006.

[6] Yu Jianhua. Chinese Painting History [M]. Jiangsu: Southeast University Press.2009. 俞剑华.中国绘画史[M].江苏: 东南大学出版 社.2009.

[7] [5 Dynasties North Song] Jing Hao et. [M]. Tianjin: Tianjin People's Fine Arts Press,1998. [五代北宋]荆浩等绘.五代北宋画集[M].天津: 天津人民美术出版社, 1998 .

[8] [Southern Song] Li Tang et. Four Paintings Of The Southern Song Dynasty [M] Tianjin: Tianjin People's Fine Arts Press,1997. [南宋]李唐 等绘.南宋四家画集[M]天津：天津人民美术出版社,1997. 
[9] [Yuan Dynasty] Huang Gongwang et. Four Painting Collections [M]. Tianjin: Tianjin People's Fine Arts Press,1994. [元代]黄公望等绘.元 四家画集[M].天津: 天津人民美术出版社,1994.

[10] Liu Yuwen et. Selected Famous Paintings In Abroad And China I [M]. Shanghai: Shanghai Literature And Art Press,1999. 刘育文等编.海外 中国名画精选 I[M].上海: 上海文艺出版社,1999.

[11] Liu Yuwen et. Selected Famous Paintings In Abroad And China II [M]. Shanghai: Shanghai Literature And Art Press,1999. 刘育文等编.海外 中国名画精选 II[M].上海: 上海文艺出版社, 1999 .

[12] Liu Yuwen et. Selected Famous Paintings In Abroad And China III [M]. Shanghai: Shanghai Literature And Art Press,1999. 刘育文等编.海外 中国名画精选 IIIIM].上海: 上海文艺出版社,1999. 